\title{
YHTEISTYÖSTÄ KUMPPANUUDEKSI - TURUN KAUPUNKI JA JÄRJESTÖT HYVINVOINTIA EDISTÄMÄSSÄ
}

Turku 2029 -kaupunkistrategiassa todetaan, että puitteet kaupunkilaisten hyvinvoinnille luodaan laaja-alaisella yhteistyöllä kolmannen sektorin kanssa. Turun kaupungin hyvinvointitoimiala on rakentanut strategian mukaisesti osaltaan monipuolisesti julkisen ja kolmannen sektorin kumppanuuksia. Esimerkiksi Turun Kaupunkilähetys ry:n kanssa yhteistyötä kaupunkilaisten hyvinvoinnin eteen on tehty jo 130 vuoden ajan. Yhteistyö on tiivistynyt sopimuksin todennetuksi kumppanuudeksi.

Kolmas sektori on tärkeä yhteistyökumppani julkiselle hallinnolle. Sosiaali- ja terveyspalvelu-uudistuksen (sote) ja maakuntauudistuksen rakentuessa kolmannen sektorin merkitys tullee vain kasvamaan, mutta vielä ei tiedetä, miten se konkretisoituu. Kolmas sektori palveluntuottajana on vahvasti esillä, mutta miten tulevaisuudessa hyödynnetään kansalaistoiminnan eri ulottuvuudet?

Tässä katsauksessa tarkastellaan julkisen ja kolmannen sektorin kumppanuuksien nykytilaa ja pohditaan, miten kumppanuuksia tulee soten aikakaudella kehittää. Erityishuomion kohteena ovat kuntoutukseen liittyvät kumppanuudet.

\section{Kumppanuus}

Kumppanuus voidaan määritellä kahden tai useamman autonomisen toimijan väliseksi pitkäjänteiseksi yhteistyöksi, jonka perustana on keskinäinen luottamus. Määritelmän mukaan osapuolet ovat toisiinsa nähden autonomisia eli riippumattomia - niin pitkälle kuin se on mahdollista. Kumppanit ovat itsenäisiä päätöksentekijöitä, ja ne voivat milloin tahansa päättää osallistua tai olla osallistumatta yhteistyöhön. Autonomisuudesta huolimatta pitkäjänteisyys liittyy hyvään kumppanuuteen, sillä toimijoiden välinen luottamus ei synny hetkessä. Toimijat voivat olla yksittäisiä ihmisiä, ihmisryhmiä tai kokonaisia organisaatioita ja näin yhteistyö voi siis olla ihmisten, ryhmien ja/tai organisaatioiden välistä. (Esimerkiksi Oravasaari \&t Järvensivu 2012.)

Kumppanuuksien rakentumisessa yksi tärkeä elementti on kahden ihmisen konkreettinen kohtaaminen, jonka jälkeen yhteistyö ja yhteydenotot puolin ja toisin tuovat konkretiaa työhön ja vievät asioita eteenpäin (vrt. esim. Alasoini 2011).

\section{Järjestöt kaupungin kumppanina}

Järjestöjen ja kaupungin välinen kumppanuus voidaan jakaa operatiiviseen, taktiseen ja strategiseen kumppanuuteen. Jotta järjestötyön koko kapasiteetti saadaan käyttöön, tarvitaan pidemmän linjan suunnitelmia, jotka luovat vakautta sekä varmuutta työn jatkumiseen ja yhteistyöhön. Operatiivisesta ja taktisesta kumppanuudesta on aika siirtyä strategiseen 
kumppanuuteen. (Maijanen \& Haikara 2014.)

Kuntien ja järjestöjen välinen yhteistyö ja ennaltaehkäisevä työ tuovat kuntatoimijan lähemmäs asukkaitaan (Pakkanen 2013). Keskusteltaessa järjestöjen ja kaupungin kumppanuudesta tulee aina ottaa huomioon, että toiminta ei kehity organisaatio- tai työntekijäkeskeisesti ylhäältä alaspäin. Järjestötyön näkökulmasta työnkehittämisen lähtökohtana on aina toiminnantaso eli ihmisten arjesta esiin nousevien kipupisteiden löytyminen ja näihin haasteisiin vastaaminen.

\section{Turun Kaupunkilähetys ry Turun kaupungin kumppanina}

Turun Kaupunkilähetys ry on perustettu vuonna 1880 ja on Turun alueen vanhin toiminnassa oleva sosiaalialan järjestö, jolla on pitkät perinteet järjestöjen ja kunnan välisen yhteistyön kehittämisessä. Se on ollut aloittamassa 1900-luvun alkupuolella kouluruokailua Turussa. Nykyään järjestö tekee kansalaistoiminnan lähtökohdista työtä nuorten aikuisten ja yli 60-vuotiaiden parissa. Yhdistys omistaa myös Turun Iso-Heikkilässä sijaitsevan palvelutalo Iso-Heikin.

Vapaaehtoistyöntekijöiden työpanokseen perustuvien järjestöjen tulee olla järjestötoimijoina luotettavia ja niiden tulee pitää huolta vapaaehtoistyöntekijöistään. Järjestö ja sen vapaaehtoiset muodostavat yhteisön, joka tukee tuen tarvitsijan lisäksi omaa aikaansa antavan vapaaehtoistyöntekijän voimavaroja (vrt. esim. Harju \&t Niemelä 2011). Turun Kaupunkilähetys ry:n kokemuksen mukaan laadukkaaksi koettu vapaaehtoistyö edellyttää kuitenkin kokonaiskoordinointia eli myös palkattua työntekijäresurssia (vrt. Valliluoto 2014).

Kansalaisyhteiskunta toteutuu parhaiten silloin, kun yhteistyöverkostot ja niiden väliset prosessit on pohdittu riittävän hyvin. Asiakastyön rajapinta, päätöksenteon prosessit ja vastuiden miettiminen ovat asioita, jotka tulee hoitaa hyvin, jotta toiminta on laadukasta. Näin ollen voidaan todeta, että vapaaehtoistoiminta ei ole ratkaisu väheneviin resurssikysymyksiin, vaan se on ja sen tulee olla myös tulevaisuu- dessa oma itsenäinen kokonaisuutensa, jonka toiminta-alue on ongelmia ehkäisevä työ.

\section{Kumppanuuden kehittämisprosessi}

Kumppanuuden kehittäminen on aina prosessi, joka etenee harvoin lineaarisesti. Prosessissa voidaan kuitenkin tunnistaa muutamia keskeisiä toisiaan vaiheittaisesti seuraavia vaiheita tai toimenpiteitä, joita ovat 1) yhteistyön tarpeen tunnistaminen, 2) tarvittavien kumppanien kartoittaminen ja rekrytointi kumppaneiksi, 3) yhteisten tavoitteiden ja toimintatapojen sopiminen, 4) yhteistyön käynnistäminen ja juurruttaminen sekä 5) toiminnan ja tavoitteiden saavuttamisen arviointi ja seuranta yhdessä.

Kaikki edellä luetellut vaiheet tai toimenpiteet ovat tärkeitä, sillä yhdenkin toteuttaminen heikosti voi rapauttaa kumppanien välistä luottamusta ja sitoutumista. Luottamuksen ja sitoutumisen edistäminen ei näin ollen olekaan erityisesti minkään erillisen vaiheen tai toimenpiteen tavoite, vaan ne ovat jatkuvasti kumppanuusprosessin keskiössä.

Luottamuksen ja sitoutumisen edistäminen edellyttää oikeanlaisia rakenteita ja prosesseja, riittävästi aikaa, resursseja ja kannustimia yhteistyöhön sekä avoimeen dialogiin perustuvia toimintamalleja. Toimijoiden väliset suhteet ja roolit, vastuunjako ja päätöksentekomekanismit on määriteltävä selkeästi, jotta toimijat tietävät, miten kumppanuus toimii, kuka tai ketkä ovat vastuussa mistäkin tehtävistä ja miten asioista päätetään yhdessä.

Kirjoitetut tai kirjoittamattomat sopimukset kuuluvat hyvän kumppanuuden rakenteisiin. Kumppaneiden kesken on sovittava vähintään siitä, mitä kumppanuudella tavoitellaan, miten kumppanuustoimintaa koordinoidaan, mihin ja millä tavoin osapuolten tulee sitoutua ja miten tieto liikkuu osapuolten välillä. Kirjalliset sopimukset turvaavat toiminnan jatkuvuuden, vaikka avainhenkilöt vaihtuisivatkin. Liian tarkat kirjalliset sopimukset voivat kuitenkin heikentää toimijoiden autonomisuuden ja osallisuuden tunnetta, mikä pitkällä aikavälillä voi myös rapauttaa luottamuksesta nousevaa sitoutumista. 


\section{KOHTI KUMPPANUUKSIA}

(muk. Vapaaehtoistoiminnan ja hoivayritysten kumppanuusmalli/Napari-hanke, 2012.)

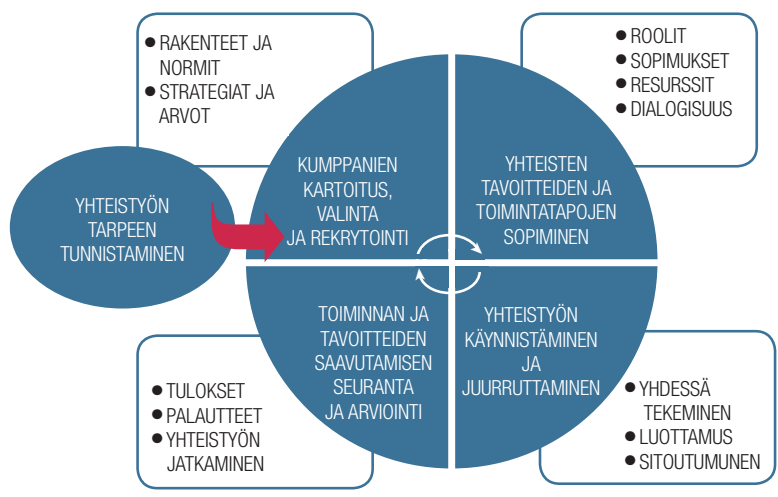

Kuva 1. Kohti kumppanuuksia.

Kumppanuustyön monimuotoisuus vaatii jatkuvaa eri elementtien yhteensovittamista ja tasapainottamista. Sitä on toteutettava paitsi tulevia tilanteita ennakoiden, myös yllättäen muuttuviin tilanteisiin sopeutuen. Kumppanuuden rakentamista ei useinkaan kannata aloittaa kaikkein vaikeimpien haasteiden ratkaisemisesta, sillä niissä epäonnistuminen voi heikentää sitoutumista jatkoyhteistyöhön. Parempi kumppanuuden kehittämisstrategia voikin olla se, että aloitetaan selkeämpien ja yksinkertaisempien haasteiden ratkaisemisesta ja siirrytään sitten luottamuksen sekä sitoutumisen kehittyessä kohti haastavampia tavoitteita ja toimenpiteitä.

\section{Julkisen ja kolmannen sektorin yhteistyö Turussa}

Julkisen ja kolmannen sektorin yhteistyön kehittäminen on osa Turku 2029 -kaupunkistrategiaan liittyvän Hyvinvointi- ja aktiivisuus -ohjelman toimeenpanoa. Sosiaali- ja terveyslautakunta päätti 15.9.2015 kokouksessaan järjestöyhteistyön kehittämistä tukevista toimenpiteistä, joita ovat avustustoiminnan linjaukset, tilaratkaisut ja soveltuvien toimintojen siirto järjestöjen hoidettavaksi. Huhtikuussa 2016 lautakunnalle esitettiin yhteistyön etenemisen tilannekatsaus sekä seuraavia jatkotoimenpide-ehdotuksia:
1. Turun kaupungin hyvinvointitoimiala luovuttaa tilojaan pääsääntöisesti vastikkeetta sellaisten järjestöjen käyttöön, joiden toiminta tukee vahvasti sosiaali- ja terveydenhuollon toimintaa, kuten kuntoutusta.

2. Avustuspolitiikan linjaukset tarkistetaan ja vakiintuneiden kumppaneiden kanssa tehdään 2-3 vuoden kestoisia kumppanuussopimuksia.

3. Vapaaehtoistoimintaa edistetään.

Turun kaupungin ja Turun Kaupunkilähetys ry:n kumppanuus tiivistyi julkisen ja kolmannen sektorin kehittämishankkeen myötä. Vuosina 2014-2015 järjestön toiminnanjohtaja Katja Suominen oli kutsuttuna Turun kaupungin hyvinvointitoimialan nimeämään työryhmään, jonka tavoitteena oli pohtia julkisen ja kolmannen sektorin yhteistyön kehittämistä 60+ -vuotiaiden parissa (Hellstén 2015). Työryhmässä nähtiin kaupungin ja kolmannen sektorin yhteistyö ensisijaisen tärkeänä. Työn toivottiin olevan pitkäjänteistä ja suunnitelmallista sekä perustuvan tasavertaiseen kumppanuuteen. Yhteisenä tavoitteena nähtiin eri toimijoiden rajapintojen tärkeyden huomioiminen ja niistä tiedottaminen päällekkäisen työn välttämiseksi. Vapaaehtoistyötä pidettiin tärkeänä ja ymmärrettiin, että se vaatii varoja ja työvoimaresursseja. Keskusteluissa todettiin tärkeäksi järjestöjen ajan hermolla oleva rooli ja niiden mahdollisuus tuoda asiakkaan ääni kuuluviin.

\section{Asiakkaan polku -hanke - yhteinen tavoite saavutetaan yhdessä toimien}

Sitran Aktiivinen kuntalainen - ja Palvelutori Turussa -projekteissa oli todettu, että nykyinen palveluverkko ei palvele turkulaisia ikäihmisiä tasapuolisesti. Vastauksena syntyi Asiakkaan polku -hanke, jossa Turun Kaupunkilähetys ry:n lisäksi mukana ovat Turun Lähimmäispalveluyhdistys, Daisy Liitto, Fingerroosin säätiö, MLL:n Varsinais-Suomen piiri, Omaiset Mielenterveystyön tukena LounaisSuomen yhdistys (nykyisin Varsinais-Suomen mielenterveysomaiset - FinFami ry), Muistiyhdistys ja Varsinais-Suomen ja Satakunnan Muistiluotsi. 
Yhdistykset totesivat yhdessä Turun kaupungin edustajien kanssa, että

1. sosiaali- ja terveysalan järjestöjen tukitoiminta tulee tuoda selkeämmin osaksi Turun kaupungin tukitoimintaa ja ennaltaehkäisevää työtä

2. kaupungin alueella tulee selkiyttää tukea tarvitsevan asiakkaan "Asiakkaan polkuja" kaupungin palvelujen ja järjestöjen toiminnan välillä sekä eri järjestöjen välillä ja

3. eri-ikäisten ja eri elämänvaiheissa työtä tekevien toimijoiden voimavaroja tulee hyödyntää suunnitelmallisesti ja yhteistyötä kehittää.

Turun Kaupunkilähetys ry sai Asiakkaan polku -hankkeelle RAY:n julkisen ja järjestöjen yhteistyön teemarahoituksen vuosiksi 2016-2017. Turun kaupungin hyvinvointitoimiala ja järjestö ovat tehneet hankkeen osalta yhteistyösopimuksen, joka sisältää muun muassa työntekijäresurssin, asiakkaiden ohjauksen, viestinnällisen ja taloudellisen yhteistyön.

\section{Hankkeesta laajempiin kokonaisuuksiin}

Yksittäiseen hankkeeseen liittyvän sopimuksen pohjalta alettiin kehittää laajempaa kumppanuussopimusmallia. Ensimmäiset mallin mukaiset mutta kuitenkin kullekin järjestölle yksilölliset sopimukset solmittiin keväällä 2017 Turun kaupungin hyvinvointitoimialan ja vakiintuneiden kumppaneiden - Turun Kaupunkilähetys ry:n, Lähimmäispalveluyhdistys ry:n, Turun Ensi- ja turvakoti ry:n, Turun Icehearts ry:n, Auralan Nuoret ry:n, Suomen Punaisen Ristin, Varsinais-Suomen Muistiyhdistys ry:n, Folkhälsan Syd Ab:n, Turun seudun lihastautiyhdistys ry:n avustajakeskuksen, MLL:n Varsinais-Suomen piirin ja Lounais-Suomen Mielenterveysseura ry:n Turun kriisikeskuksen - kesken.

Sopimusten tavoitteena on pitkäjänteinen ja yhteiseen kehittämiseen tähtäävä toiminta. Kumppanuussopimuksilla on esimerkiksi sovittu muistikuntoutuksen toteuttamisesta yhteistyössä, maahanmuuttajaäitien osallisuuden lisäämisestä ystävätoiminnalla, avustajakeskustoiminnasta, kriisitukityöstä ja traumati- soituneiden maahanmuuttajien tilanteen vakauttamisesta.

Nykyisin Turun kaupungin hyvinvointitoimialan ja järjestöjen kumppanuus- ja yhteistyösopimukset luokitellaan kolmeen ryhmään, joiden tavoitetasot on määritelty vuoden 2017 strategisessa sopimuksessa.

1. Laaja-alainen kehittämiskumppanuus voi rakentua joko järjestön tai kaupungin aloitteesta, kun yhteistyötä on jo tehty pidempään ja luottamus on syntynyt. Tavoitteena on kehittää yhdessä kaupunkilaisten hyvinvointia ja terveyttä ja/tai sosiaali- ja terveyspalveluja tukevia toimintoja. Kumppanuudessa hyödynnetään molempien osapuolien osaamista, ja kumpikin hyötyy kumppanuudesta. Järjestön on toimitettava selvitys avustuksen käytöstä ja seuraavan vuoden toiminta- ja taloussuunnitelma sosiaali- ja terveyslautakunnalle avustuksen anomista varten.

2. Yksittäiseen projektiin tai toimintaan liittyvässä sopimuksessa määritellään sopimuksen tarkoitus ja se, mihin kumpikin osapuoli sitoutuu, miten pitkäksi aikaa ja kuinka sopimuksen toteutumista seurataan. Tällaisen sopimuksen perusta voi olla esimerkiksi STEAlle tai muille ulkopuolisille rahoittajille annetuissa aiesopimuksissa tai lausunnoissa. Sopimus syntyy, mikäli rahoittaja tekee asiasta myönteisen päätöksen.

3. Tilojen luovutukseen liittyvät yhteistyösopimukset. Järjestölle, jonka toiminta tukee vahvasti sosiaali- ja terveydenhuollon toimintaa, annetaan tila ilman rahallista vastiketta. Tällöin järjestön kanssa tehdään yhteistyösopimus, jossa kuvataan, millä tavalla järjestön toiminta tukee ja täydentää hyvinvointitoimialan omaa toimintaa. Esimerkiksi Turun A-kilta on saanut maksutta käyttöönsä hyvinvointitoimialalta kerhotilan, kuntosalin, uima-altaan ja puutyöverstaan jäsenistönsä ryhmätoimintoja varten. Toiminta tukee jäsenistön sosiaalista kuntoutumista, vuorovaikutusta ja myös työelämätaitojen hankkimista.

\section{Kumppanuustyön edetessä palvelupuutteisiin vastataan yhdessä}

Turun kaupungin ja Turun Kaupunkilähetys 
ry:n kumppanuus on edennyt vaiheeseen, jossa asiakasrajapinnasta esiin nousseisiin palvelupuutteisiin vastataan yhdessä. Organisaatioiden välisessä kumppanuussopimuksessa on kuvattu muun muassa järjestön nuorten aikuisten tukitoiminta. Järjestön TUAS - Nuorten tuetun asumisen toiminnassa tuetaan itsenäistä elämää aloittavia 18-25-vuotiaita syrjäytymisvaarassa olevia nuoria vapaaehtoistoimintaan perustuvan tukihenkilötoiminnan keinoin. Järjestön kehittämässä Oma Koutsi -toiminnassa puolestaan tuetaan 17-29-vuotiaita nuoria aikuisia arjenhallinnassa sekä työhön ja opiskeluun liittyvissä haasteissa verkostotyön ja vapaaehtoisten tukihenkilöiden, "koutsien", tuella. Vuosittain järjestön tukitoiminnan piirissä on yli sata nuorta. Toiminnan yhteistyöverkosto on laaja. Yhteistyökumppaneina ovat Turun kaupungin hyvinvointitoimialan lisäksi muiden muassa Ylioppilaiden terveydenhuoltosäätiö (YTHS), Turun ammatti-instituutti, Turun TEtoimisto ja Turun kaupungin Nuorisopalvelut.

Vapaaehtoisten koutsien rooli nuoren elämässä on kokemusten perusteella merkityksellinen. Nuoret ovat kokeneet heidän arkeensa ulottuvan ja virka-aikojen ulkopuolella tapahtuvan säännöllisen ja yksilöllisen tuen tärkeäksi. Nuoret tarvitsevat tsemppaajaa, joka tukee nuorta erilaisten työllistymiseen, kuntoutukseen tai opiskeluun liittyvien kuntoutus- ja aktivointisuunnitelmien käytäntöön saattamiseksi. Tähän tarpeeseen vastaa vapaaehtoinen koutsi.

Noin kolmanneksella järjestön tukitoiminnan piiriin tulleista nuorista on niin vaikea elämäntilanne, että nuori tarvitsee säännöllistä ja yksilöllistä ammattilaisen tukea. STEArahoitteisessa toiminnassa pääpaino ei voi olla vain ammatillisessa tuessa, joten nuoria on jouduttu ohjaamaan muiden toimijoiden piiriin. Oma Koutsi -toiminnan lähtökohtana on yhden luukun periaate. Erityisen vaikeissa tilanteissa oleville nuorille voitaisiin myös tarjota vapaaehtoisen koutsin tukea, mutta se edellyttäisi ennen koutsisuhteen aloittamista lyhyttä ammatillista interventiota.

Ongelmaan vastatakseen järjestö etsi erilaisia rahoitusmahdollisuuksia ja keinoja, joi-

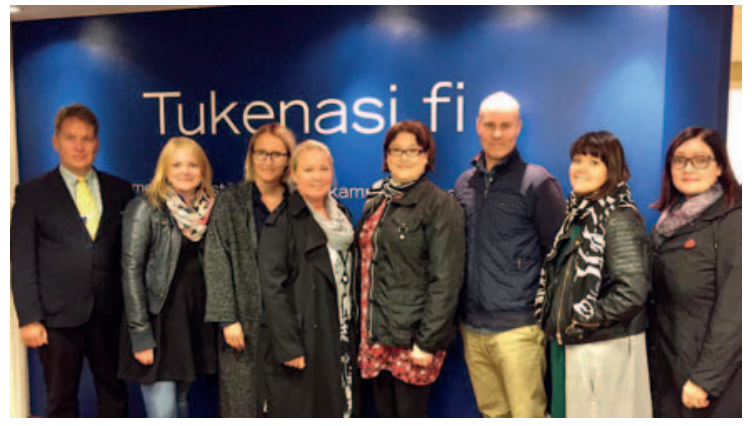

Kun tavoite on yhteinen, niin vanhat ja vakaatkin organisaatiot ovat ketteriä.

den avulla voitaisiin tarjota nuorelle lyhytkestoista ammatillista tukea ja tutkia tämän kokonaisuuden hyötyä nuorille. Samanaikaisesti Kelalla oli haussa rahoitushaku, jossa etsittiin ideoita ja kehittämishankkeita erityisesti nuorten ammatillisen ja sosiaalisen kuntoutuksen yhdistämiseen. Turun Kaupunkilähetys ry kutsui koolle eri organisaatioiden edustajista koostuvan ryhmän pohtimaan yhteistyömahdollisuuksia.

Tapaamiseen osallistuivat nopealla aikataululla Turun kaupungin palvelujohtaja Mika Helva, Kelan Läntisen vakuutuspiirin etuuskäsittely päällikkö Minna Nilsson, Turun yliopiston ma. sosiaalipolitiikan professori Minna Ylikännö, Turun kaupungin hyvinvointitoimialan suunnittelupäällikkö Jaana Halin, Turun kaupungin työllisyyspalvelukeskuksen tuotantopäällikkö Ari Laaksonen sekä Turun Kaupunkilähetys ry:stä toiminnanjohtaja Katja Suominen, hankevastaava Liisa Love ja hankesuunnittelija Kaisa Lundén. Voidaankin sanoa, että vanhojen ja vakaiden organisaatioiden ketteryyttä on viime vuosina turhaan arvosteltu. Kun tavoite on yhteinen, myös tahtoa ja ketteryyttä löytyy. Tapaamisen päätteeksi todettiin yhteisesti, että aihe on tärkeä ja Turun Kaupunkilähetys ry hakee rahoitusta Kelalta muiden ollessa mukana yhteistyökumppaneina.

\section{Sote tulee - kolmas sektori on tärkeä osa!}

Kolmas sektori ja järjestöjen rooli mainitaan sote-suunnitelmissa, mutta mikä rooli niil- 
lä tulee olemaan? Miten käsite kolmas sektori määritellään? Nähdäänkö järjestöt vain sote-palvelujen tuottajina vai huomioidaanko myös niiden kansalaisjärjestön rooli? Ennaltaehkäisevää sosiaali- ja terveystyötä tullaan edistämään yhteistyössä kansalaisjärjestöjen kanssa. Mitä sitten merkitsee, kun suunnitelmien mukaan hyvinvoinnin edistäminen tulee jäämään kuntien tehtäväksi? Missä vastuiden raja kulkee? On järjestöjä, jotka sijoittuvat selvästi soten toimintakenttään, ja järjestöjä, jotka ovat sekä soten että kunnan toimijoita. Kysymyksiä on paljon, vastauksia vielä etsitään. Kuntien ja maakuntien on kuitenkin huolehdittava ja tarvittaessa vahvistettava järjestöjen kansalais- ja vapaaehtoistoiminnan toimintamahdollisuuksia. Järjestöjä tarvitaan muuttuvassa sotessakin! Toivottavasti Turun kaupungin hyvinvointitoimialan kehittämä järjestökumppanuusmalli leviää laajempaankin käyttöön. Kiinnostusta sitä kohtaan ovat esittäneet monet kunnat.

Tulosten merkitys: Turun kaupungin ja järjestöjen yhteistyön kehittyminen yhä tiiviimmäksi on luonut uudenlaisia mahdollisuuksia ketterään ja arjen tarpeista esiin nousevaan kehittämistoimintaan. Tulevaisuudessa onkin tärkeää tunnustaa järjestöjen osaaminen ja rooli matalankynnyksen toiminnan kehittäjänä sekä hyödyntää entistä suunnitelmallisemmin eri toimijoiden välisiä palvelupolkuja.

Avainsanat: kunta, sosiaali- ja terveysjärjestö, kumppanuus, yhteistyö, vapaaehtoistoiminta, kansalaistoiminta

Jaana Halin, FM, HuK, suunnittelupäällikkö, Turun kaupunki, hyvinvointitoimiala

Kristiina Hellstén, FT, THM, projektipäällikkö, Turun kaupunki, hyvinvointitoimiala

Katja Suominen, sosionomi (YAMK), toiminnanjohtaja, Turun Kaupunkilähetys ry

\section{Lähteet}

Alasoini T (2011) Hyvinvointia työstä. Kuinka työelämää voi kehittää kestävällä tavalla. Tykes. Raportteja 76, Helsinki.

Harju A, Niemelä J (2011) Järjestöjen taloudelliset toimintaedellytykset. Oikeusministeriön selvityksiä ja ohjeita 2, Helsinki.

Hellstén K (2015) Julkisen ja kolmannen sektorin yhteistyön kehittäminen - kohti kumppanuuksia. (Raportti liittyy Sitran rahoittamaan Palvelutori Turussa -projektiin, joka toteutui 08/201403/2015.) Julkaisematon käsikirjoitus.

Maijanen H, Haikara P (2014) Kumppanuuskäsikirja. Näkökulmia monitoimijaisen yhteistyön kehittämiseen. Kaakkois-Suomen sosiaalialan osaamiskeskuksen julkaisuja A. 8:2014, Lappeenranta.

Oravasaari T, Järvensivu T (toim.) (2012) Vapaaehtoistoiminnan ja hoivayritysten kumppanuusmalli Vapaaehtoiset kumppaneiksi (Vapari) -hanke. Laurea-ammattikorkeakoulu, Vantaa.

Pakkanen E (2013) Kuntien ja järjestöjen välinen yhteistyö. Kuntatoimijoiden näkemyksiä KaakkoisSuomen alueen järjestöyhteistyöstä. Kandidaatintutkielma, Yhteiskuntapolitiikka, Yhteiskuntatieteiden ja filosofıan laitos, Jyväskylän yliopisto. Kaakkois-Suomen sosiaalialan osaamiskeskus 0y Socom, Lappeenranta.

Valliluoto S (2014) Vapaaehtoistoiminnan mahdollisuuksista ja esteistä. Kilpailu- ja kuluttajaviraston selvityksiä 4, Helsinki. 